DOI: 10.4274/tod. galenos.2019.87004

Turk J Osteoporos 2019;25:99-104

\title{
Prevalence and Risk Factors of Osteoporosis in Men with Chronic Obstructive Pulmonary Disease in Kars Province
}

\author{
Kars Ilinde Kronik Obstruktif Akciğer Hastalığı Olan Erkeklerde Osteoporoz Sıklığı ve Risk \\ Faktörleri
}

(D) Fatih Bağcıer, (D) Gökhan Perinçek*

Kars Harakani State Hospital, Clinic of Physical Medicine and Rehabilitation, Kars, Turkey

*Kars Harakani State Hospital, Clinic of Chest Disease, Kars, Turkey

\section{Abstract}

Objective: Chronic obstructive pulmonary disease (COPD) is an important cause of morbidity and mortality today. Osteoporosis is known to be seen more commonly in COPD patients. This study aimed to evaluate the prevalence and risk factors of osteoporosis in men with COPD in Kars province.

Materials and Methods: In this retrospective study performed on 88 male patients diagnosed with COPD, demographic data of the patients were recorded. The histories that duration of smoking and the use of steroid were documented. Pulmonary function tests and bone mineral densities were analyzed from their files.

Results: The prevalence of osteopenia and osteoporosis in our study was $46.5 \%$ and $50 \%$, respectively. The patient's age, smoking duration, COPD stage, and use of steroid history was significantly associated with osteoporosis $(p<0.05)$. This relationship could not be demonstrated in the body mass index.

Conclusion: The advanced stage of the disease, smoking, and the use of steroid should be a stimulant for osteoporosis in COPD patients. Early diagnosis and treatment are important in terms of protection from possible vital complications, especially fractures.

Keywords: Osteoporosis, chronic obstructive pulmonary disease, cigarette

\section{Öz}

Amaç: Kronik obstrüktif akciğer hastalı̆ı (KOAH), günümüzde önemli bir morbidite ve mortalite nedenidir. KOAH'li hastalarda osteoporozun daha sık görüldüğü bilinmektedir. Bu çalışma, Kars ilindeki KOAH’li erkeklerde osteoporoz prevalansını ve risk faktörlerini değerlendirmeyi amaçlamıştır.

Gereç ve Yöntem: KOAH tanısı olan 88 erkek hasta üzerinde retrospektif olarak yapılan çalışmada hastaların demografik verileri kaydedildi. Sigara kullanım süresi, steroid kullanım öyküleri dokümante edildi. Solunum fonksiyon testleri ve kemik mineral yoğunlukları dosyalarından analiz edildi.

Bulgular: Çalışmamızda osteopeni ve osteoporoz prevalansı sırasıyla \%46,5 ve \%50 idi. Hastanın yaşı, sigara kullanım süresi, KOAH evresi, steroid kullanım öyküsü osteoporoz ile anlamlı olarak ilişkiliydi $(p<0,05)$. Bu ilişki vücut kitle indeksinde gösterilemedi.

Sonuç: KOAH'li hastalarda hastalığın ileri evre olması, sigara ve steroid kullanımı osteoporoz açısından uyarıcı olmalıdır. Erken teşhis ve tedavi başta kırık olmak üzere olası hayati komplikasyonlardan koruması yönüyle önemlidir.

Anahtar kelimeler: Osteoporoz, kronik obstrüktif akciğer hastalığı, sigara

\section{Introduction}

Chronic obstructive pulmonary disease (COPD) is a completely irreversible disease characterized by airflow restriction due to the abnormal inflammatory response of lungs, particularly cigarettes, to harmful particles and gases. COPD, which has a multi-systemic involvement especially in lungs, may cause osteopenia and osteoporosis in bones $(1,2)$. The main goal of COPD treatment is to eliminate the symptoms associated with pulmonary dysfunction. On the other hand, possible complications, which may develop with the progression of the disease and the effect of drugs used in the treatment of the disease, should be considered (3). In COPD patients, osteoporosis may develop due to lung disease (decrease in

Address for Correspondence/Yazıșma Adresi: Fatih Bağcıer MD, Kars Harakani State Hospital, Clinic of Physical Medicine and Rehabilitation, Kars, Turkey Phone: +90 5442429042 E-mail: bagcier_42@hotmail.com ORCID ID: orcid.org/0000-0002-6103-7873 Received/Geliş Tarihi: 23.07.2019 Accepted/Kabul Tarihi: 05.09.2019

${ }^{\oplus}$ Copyright 2019 by the Turkish Osteoporosis Society

Turkish Journal of Osteoporosis published by Galenos Publishing House. 
dyspnea-related activity, systemic inflammation, decrease in skeletal muscle mass), treatment (corticosteroid treatment), aging (hypogonadism, inactivity, decrease in muscle mass) and habits (smoking, alcohol) (4). Osteoporosis is a progressive metabolic bone disease that results in increased bone fracture and fracture tendency as a result of low bone mass and disruption of micro-architecture of bone tissue (5). It may cause multiple fractures in the spine, causing chronic pain, shortening of the length, kyphotic posture, and consequently respiratory dysfunction (6). In COPD patients, it is important to carry out the necessary examinations and preventive measures before the fracture occurs and to start the treatment of osteoporosis. Although the relationship between COPD and osteoporosis has not been fully established, they are known to have similar risk factors [smoking, older age, low level of vitamin D, long-term treatment with corticosteroids, excessive weight loss, and low body mass index (BMI)]. In this study, we aimed to determine the prevalence of osteoporosis and risk factors in COPD patients in Kars city.

\section{Materials and Methods}

This cross-sectional study was retrospectively performed in Kars Harakani State Hospital, Clinic of Chest Diseases and Physical Medicine and Rehabilitation in 2019. The records of 88 male patients with COPD between 50 and 84 years of age were evaluated for bone mineral density (BMD) and pulmonary function tests. The study was approved by the ethics committee of Kafkas University Faculty of Medicine. Patients with stable COPD, who were observed in Kars Harakani State Hospital Clinic of Chest Diseases and admitted to Kars Harakani State Hospital Clinic of Physical Medicine and Rehabilitation for diagnosis of osteoporosis and accounts for the COPD description of the Global Initiative for Chronic Obstructive Lung Disease (GOLD) criteria, were included in the study (3). Inclusion criteria were; having been followed at the COPD polyclinic for at least 2 years and being a volunteer to participate in the study. Patients with respiratory disease other than COPD, patients with other diseases that would affect bone metabolism (endocrine, metabolic, renal, hepatic, rheumatologic), and patients using drugs other than corticosteroid that would affect bone metabolism (antiresorptive drugs, diuretics, etc.) were excluded from the study.

\section{Pulmonary Function Tests and COPD Staging}

Pulmonary function tests were evaluated by experienced technicians. Forced expiratory volume (FEV1) and forced vital capacity (FVC) were measured with spirometry. FEV1/FVC ratio was calculated. COPD patients were divided into 4 stages based on FEV1 values in GOLD guidelines (7).

\section{BMD Measurements}

BMD was measured by dual-energy $X$-ray absorptiometry and Norland XR-800 was used to measure the spine (Lumbar 1-4) and hip (femoral neck) of all subjects. Results were evaluated in $\mathrm{gr} / \mathrm{cm}^{2}$. T score was used to determine how much BMD deviated from the mean of young adults. Based on World Health Organization criteria, T score $<2.5$ standard deviation (SD) was evaluated as osteoporosis, value between -1 SD and -2.5 SD was evaluated as osteopenia (8).

\section{Statistical Analysis}

Data was presented using frequency and percentage for categorical variables. The chi-square test was used to compare the groups of the categorical variables. All statistical analyses were performed by using SPSS so ware version 19 and $p$ values less than 0.05 were considered statistically significant.

\section{Findings}

Eighty-eight COPD patients aged 55-84 years participated in the study. Most of the patients (39.7\%) were between 65 and 74 years of age. BMl was normal in $36.3 \%$ of the patients. According to GOLD criteria, of the patients, 22 (25\%) had stage I, 22 (25\%) had stage II, 22 (25\%) had stage III, 22 (25\%) had stage IV COPD. According to World Health Organization criteria, 43 patients (48.8\%) had osteoporosis. The results of the relationship between lumbar spine and femoral neck BMD and other parameters are shown in Table 1.

Patients' age, smoking duration, COPD stage, use of steroid history was significantly associated with BMD. This relationship could not be demonstrated in BMI. There was a correlation between COPD stage and BMD scores of both femoral neck and lumbar spine. Similarly, there was a correlation between inhaled and oral steroid use and BMD scores of femoral neck and lumbar spine, but no correlation was found between age, smoking and lumbar spine BMD (Figure 1,2,3,4,5).

\section{Discussion}

In addition to non-modifiable risk factors such as age, sex and genetic characteristics, some modifiable factors such as nutrition and exercise habits and smoking-alcohol use play an important role in osteoporosis development. Previous studies have shown that osteoporosis is closely associated with common chronic diseases such as diabetes, hypertension, chronic kidney disease, rheumatologic disease and $\operatorname{COPD}(9,10)$. In this study, we determined the prevalence of osteoporosis, risk factors in COPD patients in Kars and planned to draw attention to the issues such as early diagnosis, treatment and prevention of possible complications of osteoporosis.

In our study, the prevalence of osteopenia and osteoporosis in COPD patients in Kars was $46.5 \%$ and $50 \%$, respectively. In the literature in the studies performed on patients with COPD, osteopenia and osteoporosis rates were shown respectively as $31.5 \%$ and $52.8 \%$ by Abbasi et al. (11) and $50 \%$ and $30 \%$ by Abu-Bakr et al. (12). Biskobing et al. (13) in their compilation reported $35-72 \%$ osteopenia and $36-60 \%$ osteoporosis in the COPD patients. Karapolat et al. (3) in their study proportioned lumbar and femur regions separately. 59.1\% femur neck, $60.0 \%$ femur ward's triangle and $61.9 \%$ lumbar osteopenia 
Turk J Osteoporos

Bağcıer and Perinçek.

2019;25:99-104

Osteoporosis with Chronic Obstructive Pulmonary Disease in Kans City

101

was detected. $4.5 \%$ femur neck, 10.0\% femur ward's triangle and $19.4 \%$ lumber osteoporosis was detected. Mansour et al. (14) reported the prevalence of osteoporosis and osteopenia in COPD patients between the ranges of $9-69 \%$ and $27-76 \%$, respectively. The reason for this wide range may be that different populations have been studied and different diagnostic methods have been used. The rates in our study were within the range defined in the literature $(13,15)$. Advanced age and smoking are common risk factors for osteoporosis and COPD $(8,16)$. The effect of smoking on osteoporotic fracture is also known, but is thought to have a limited effect on BMD. In our study, a statistically significant relationship was found between smoking duration and femoral neck osteoporosis (Figure 1). In the literature, smokers have been reported to have lower bone

Table 1. Frequency of different risk factors of osteoporosis in chronic obstructive pulmonary disease patients

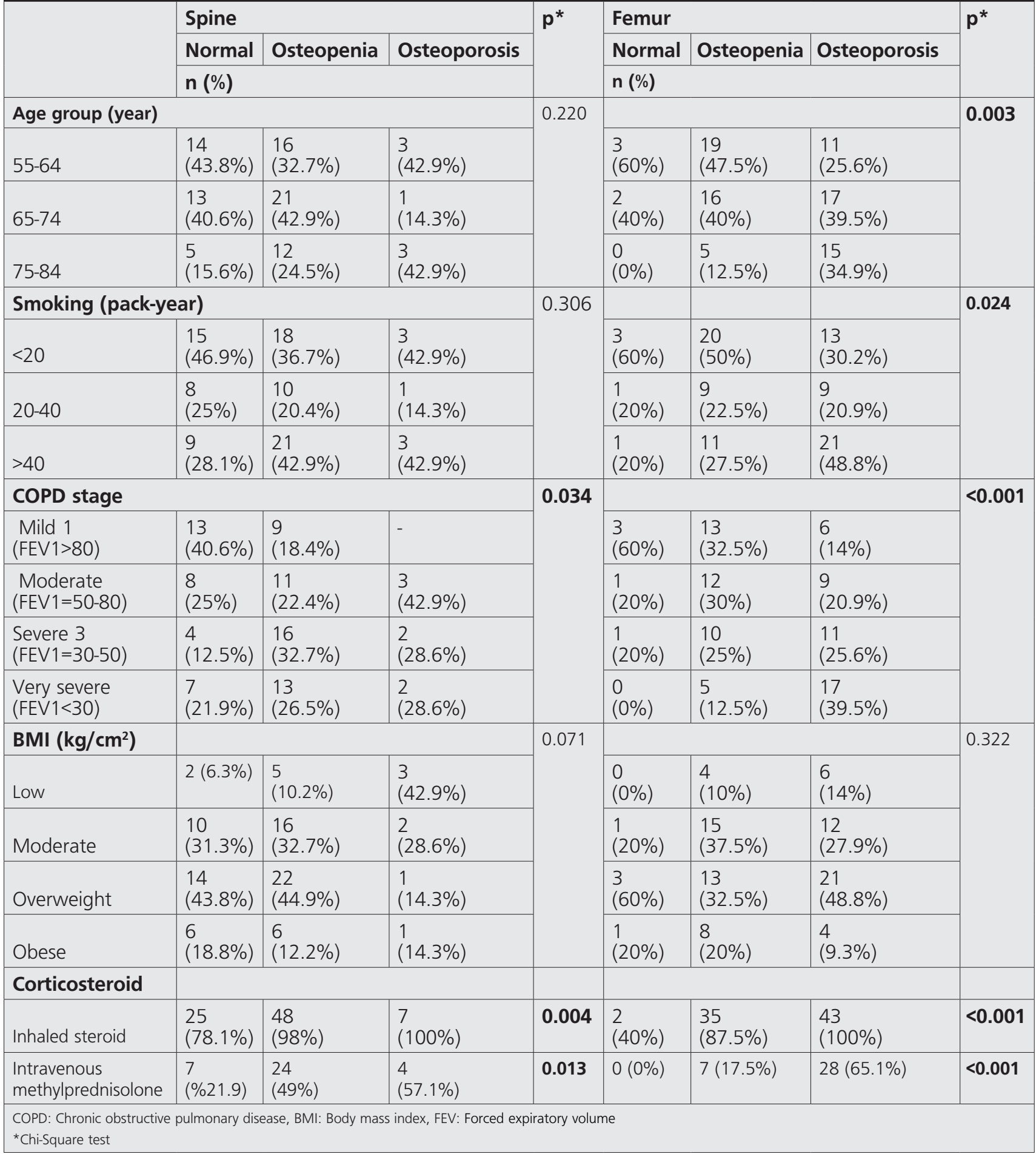




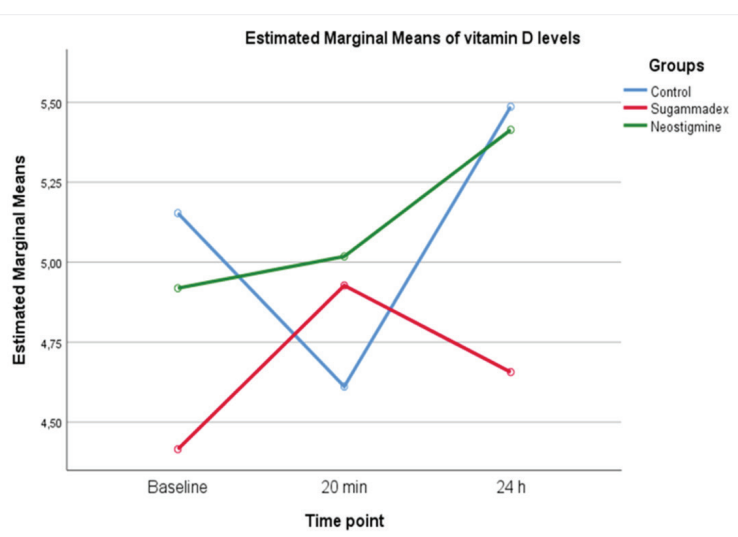

Figure 1. Interaction between osteoporosis in the femoral neck and severity of smoking

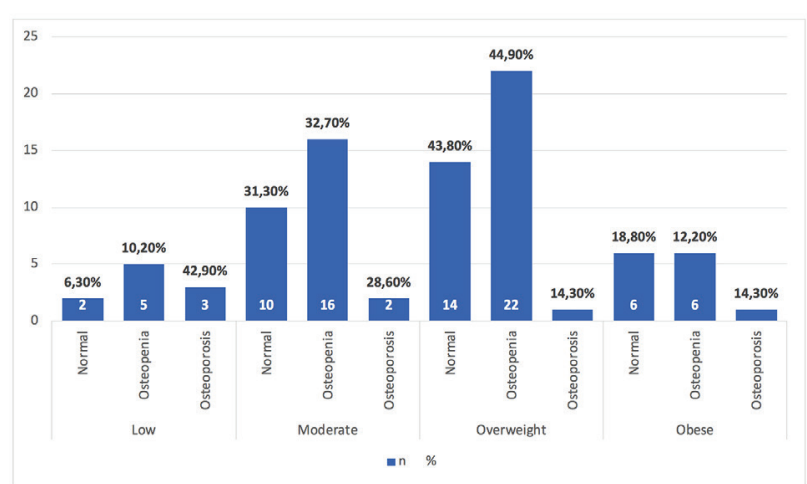

Figure 2. Interaction between osteoporosis in the spine and severity of smoking

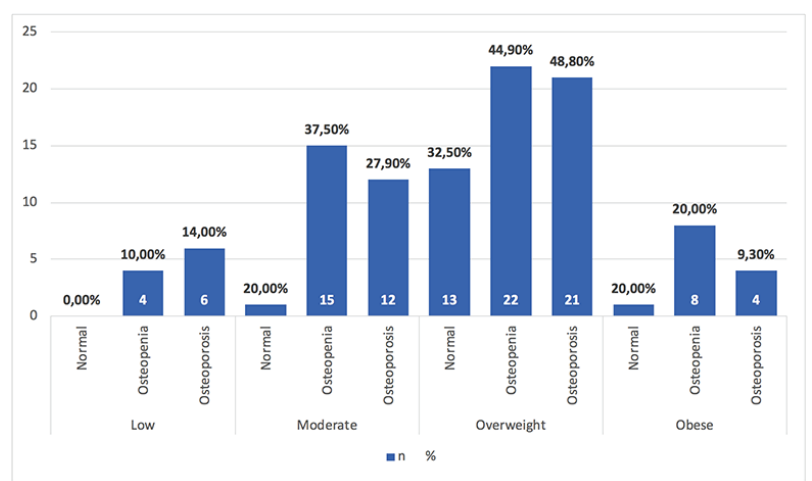

Figure 3. Interaction between osteoporosis in the femur neck and BMI

mass and a faster rate of bone loss. It is thought that women who smoke are lower in weight and therefore have earlier menopause (15). On the other hand, smoking increases blood cortisol levels and causes a decrease in BMD (17). Although the smoking rate of the patients in our study was high, the high body mass index prevented the negative correlation between osteoporosis and body mass index (Figure 2,3). In women, body weight has been shown to increase BMD both by exerting mechanical load on the skeleton and by estrogens stored in adipose tissue. However, there is no study on men about this subject (18). Studies investigating the relationship between

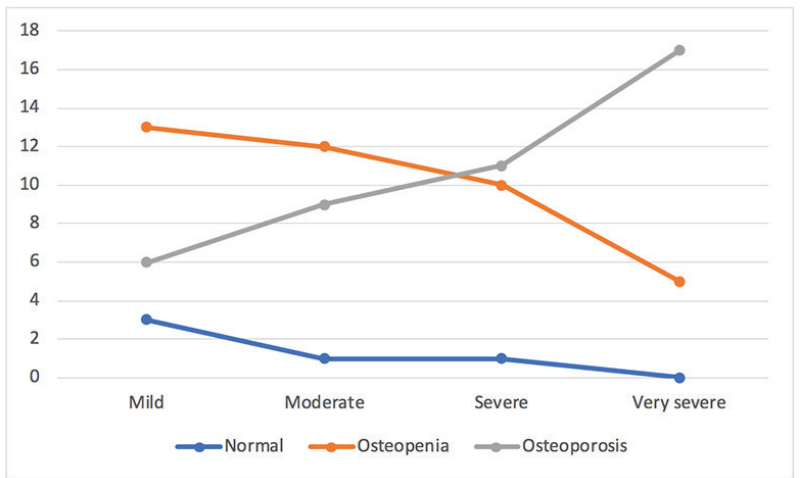

Figure 4. Interaction between osteoporosis in the femoral neck and severity of COPD

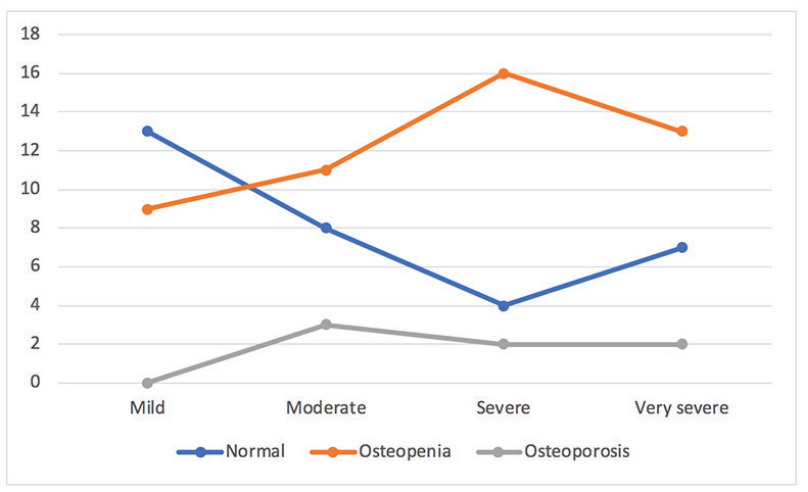

Figure 5. Interaction between osteoporosis in the spine and severity of COPD

smoking and osteoporosis in men have concluded that smoking is an important risk factor for bone loss and osteoporotic fracture $(19,20,21)$. It is even reported that the harmful effect of smoking on bone mass in men is 50\% to $300 \%$ higher than in women. This gender difference may be due to the fact that males smoke more, or estrogen has a protective effect on bone in women (16). In the literature, a correlation has been reported between osteoporosis and decreased respiratory function. Decreased FEV at first second and advanced COPD stages have been shown to correlate with low BMD. Nuti et al. (22) have shown that BMD is low in COPD patients and bone density decreases with increasing disease severity. Abbasi et al. (11) found a correlation between femoral neck BMD and COPD severity. In our study, similar to the literature, a correlation was found between COPD stages and BMD of both femoral neck and lumbar spine (Figure 4,5). The relationship between pulmonary function parameters and osteoporosis is complex. In an experimental biopsy study, bone microarchitecture was seen to be more affected in COPD patients compared to the control group (23). Therefore, it has been shown that patients with COPD have a continuous systemic inflammatory condition that leads to the release of proinflammatory cytokines such as TNF- $\alpha$, IL-1 and IL 6 . On the other hand, the increase in the production of catalytic enzyme also affects this process (11). As a result, bone resorption increases and new bone formation is 
suppressed (24). In addition, the decrease in exercise capacity of the patients with pulmonary dysfunction and therefore their dependence on the home causes predisposition to osteoporosis $(25,26)$. The use of steroids in COPD patients is also known to be associated with low BMD. In our study, this condition was evaluated and an association was found between oral and inhaled steroid use and low BMD of both femoral neck and lumbar spine. Almost all of our patients were on inhaled steroids, but there was a history of oral steroid use in patients with stage 3 and 4 COPD, but it was not clear how often and in what posology they used. Although the rate of bone loss varies depending on steroid dose and duration of use, we could not differentiate this in our study due to the reasons mentioned. In the literature, Abbasi et al. (11) detected an association between oral steroid use and femoral neck BMD. However, it has been observed that it has no effect on lumbar spine BMD. Although there have been studies in the literature that inhaled steroid use adversely affects BMD and increases fracture risk, there are also studies that argue otherwise. Langhammer et al. (27) examined the effect of inhaled corticosteroid use on BMD in 65225 adults and emphasized that inhaled corticosteroid use was associated with low bone mass. In a meta-analysis, significant reduction in bone density was reported in high-dose inhaled steroid users (>1.5 mg/day prednisone or equivalent) (28). Abbasi et al. (11) reported that inhaled steroid use did not cause BMD loss. Vitamin D deficiency has been shown to be associated with osteoporosis in COPD patients (2). Dyspnea and peripheral muscle weakness cause exercise intolerance in patients. As a result, patients prefer to live at home and are sedentary. Vitamin D is low in patients who cannot benefit from sunlight sufficiently. The fact that we did not check vitamin $D$ levels in our study may have prevented us from detecting possible BMD influences. Other limitations of our study were the fact that our patient group consisted of only male patients, the number of patients was low, corticosteroid use was evaluated retrospectively, and the exact duration and dose of steroids were not known. Randomized controlled studies involving more cases are needed to evaluate the relationship between operational risk factors and BMD. All physicians interested in osteoporosis should consider these factors when applying preventive approaches before therapeutic strategies. In this way, it is thought that mortality and morbidity caused by fractures can be prevented and treatment costs can be reduced (29).

\section{Conclusion}

In conclusion, osteoporosis may cause mortality and morbidity in patients with COPD. Patients with a history of smoking, steroid medication, advanced stage COPD should be followed up more frequently for osteoporosis and possible complications. In osteoporosis, taking preventive measures, making early diagnosis and timely planning of treatment is important.

\section{Ethics}

Ethics Committee Approval: The study was approved by the ethics committee of Kafkas University School of Medicine.

\section{Informed Consent:}

Peer-review: Internally peer-reviewed.

\section{Authorship Contributions}

Surgical and Medical Practices: F.B., G.P., Concept: F.B., G.P., Design: F.B., G.P., Data Collection or Processing: F.B., G.P., Analysis or Interpretation: F.B., G.P., Literature Search: F.B., G.P., Writing: F.B., G.P.,

Conflict of Interest: No conflict of interest was declared by the authors.

Financial Disclosure: The authors declared that this study received no financial support.

\section{References}

1. Graat-Verboom L, Smeenk FW, van den Borne BE, Spruit $M A$, Donkers-van Rossum AB, Aarts RP et al. Risk factors for osteoporosis in Caucasian patients with moderate chronic obstructive pulmonary disease: a case control study. Bone 2012;50:1234-9.

2. Cielen N, Maes K, Gayan-Ramirez G. Musculoskeletal disorders in chronic obstructive pulmonary disease. Biomed Res Int 2014;2014:965764.

3. Karapolat H, Eyigör S, Gürgün A, Kirazli Y. Erkek COPD Hastalarında Osteoporozun Değerlendirilmesi. Türk Osteoporoz Dergisi 2007;13:70-4.

4. Ionescu AA, Schoon E. Osteoporosis in chronic obstructive pulmonary disease. Eur Respir J Suppl 2003;46:64-75.

5. Cosman F, de Beur SJ, LeBoff MS, Lewiecki EM, Tanner B, Randall $S$ et al. Clinician's Guide to Prevention and Treatment of Osteoporosis. Osteoporos Int 2014; 25:2359-81.

6. Ciric Z, Stankovic I, Pejcic T, Ristic L, Rancic M, Radovic M. Osteoporosis in patients with chronic obstructive pulmonary disease. Medical Archives 2012;66:385-7.

7. Rabe KF, Hurd S, Anzueto A, Barnes PJ, Buist SA, Calverley P et al. Global strategy for the diagnosis, management, and prevention of chronic obstructive pulmonary disease: GOLD executive summary. Am J Respir Crit Care Med 2007;176:532-55.

8. Kanis JA, Melton LJ, Christiansen C, Johnston CC, Khaltaev N. The diagnosis of osteoporosis. J Bone Miner Res 1994;9:1137-41.

9. Okazaki R, Watanabe R, Inoue D. Osteoporosis Associated with Chronic Obstructive Pulmonary Disease. J Bone Metab 2016;23:111-20.

10. Kul A, Erdal A. Bone Mineral Density and Vitamin D Values in Behçet's Disease. Turk J Osteoporos 2018;24:78-83.

11. Abbasi M, Zohal M, Atapour B, Yazdi Z. Prevalence of Osteoporosis and its Risk Factors in Men with COPD in Qazvin. Int J Chronic Dis 2016;2016:4038530.

12. Abu-Bakr SM, Eldin MMG, Hafez MR, Salem SM, Qandeel HT. Assessment of osteoporosis in patients with chronic obstructive pulmonary disease. Egyptian Journal of Chest Diseases and Tuberculosis 2014;63(3):597-602.

13. Biskobing DM. COPD and osteoporosis. Chest 2002;121:609-20.

14. Mansour OF, Bakr RM, Elwahsh RA, Zanfal AM. Osteoporosis in patients with chronic obstructive pulmonary disease. Menoufia Medical Journal 2015;28:521-524.

15. Sarıdoğan ME. Osteoporozda risk faktörlerinin değerlendirilmesi. In: Sarıdoğan ME, Gökçe-Kutsal Y, editörler. Osteoporoz tanı ve tedavi kılavuzu. İstanbul, 2005:5-25.

16. Taşoğlu Ö, Özdemir O, Kutsal YG. Osteoporozlu Hastalarda Gözardı Edilen Bir Risk Faktörü: Sigara Kullanımı. Turk J Osteoporos, 2011;17:0-0.

17. Nakamura K, Takahashi S, Oyama M, Nashimoto M, Saito T, Tsuchiya $Y$, et al. Incidence and risk factors associated with hip 
fracture in institutionalised elderly people in Japan. Age Ageing 2009;38:478-82

18. Berecki-Gisolf J, Spallek M, Hockey R, Dobson A. Height loss in elderly women is preceded by osteoporosis and is associated with digestive problems and urinary incontinence. Osteoporos Int 2010:21:479-85.

19. Slemenda CW, Christian JC, Reed T, Reister TK, Williams CJ Johnston CC Jr. Long-term bone loss in men: effects of genetic and environmental factors. Ann Intern Med 1992;15;117:286-91.

20. Hannan MT, Felson DT, Dawson-Hughes B, Tucker KL, Cupples LA, Wilson PW et al. Risk factors for longitudinal bone loss in elderly men and women: the Framingham Osteoporosis Study. J Bone Miner Res 2000;15:710-20.

21. Ward KD, Klesges RC. A meta-analysis of the effects of cigarette smoking on bone mineral density. Calcif Tissue Int 2001;68:25970 .

22. Nuti R, Siviero P, Maggi S, Guglielmi G, Caffarelli C, Crepaldi G, Gonnelli S. Vertebral fractures in patients with chronic obstructive pulmonary disease: the EOLO Study. Osteoporos Int 2009;20:98998

23. Kulak CA, Borba VC, Jorgetti V, Dos Reis LM, Liu XS, Kimmel DB et al. Skeletal microstructural abnormalities in postmenopausal women with chronic obstructive pulmonary disease. J Bone Miner Res, 2010;25:1931-40.

24. Jørgensen NR, Schwarz P. Osteoporosis in chronic obstructive pulmonary disease patients. Current Opinion in Pulmonary Medicine 2008;14:122-127.

25. Hens C, Böhning W. [Does COPD affect bone mineral content?]. Pneumologie 1990;44:204-5.

26. Nishimura Y, Nakata H, Tsutsumi M, Maeda H, Yokoyama M. Relationship between changes of bone mineral content and twelve-minute walking distance in men with chronic obstructive pulmonary disease: a longitudinal study. Intern Med 1997;36:450-

27. Langhammer A, Norjavaara E, de Verdier MG, Johnsen R, Bjermer L. Use of inhaled corticosteroids and bone mineral density in a population based study: the Nord Trøndelag Health Study (the HUNT Study). Pharmacoepidemiol Drug Saf 2004;13:569-79.

28. Lipworth BJ. Systemic adverse effects of inhaled corticosteroid therapy: A systematic review and meta-analysis. Arch Intern Med 1999;159:941-55

29. Güloğlu SB. Doktor ve Hemşirelerin Osteoporoz Bilgi ve Farkındalık Düzeyi: Kesitsel Bir Çalışma. Kafkas J Med Sci 2019;9:46-53. 